\title{
Research and Application of Solar Energy Heating System for Individual Household in Western Sichuan Plateau
}

\author{
Ling $\mathrm{Li}^{1, *}$, Jiri Zhou ${ }^{2}$ \\ ${ }^{1}$ Institute of Architectural Engineering, Chengdu Textile College, Chengdu, 611731, China. \\ ${ }^{2}$ School of Mechanical Engineering, Southwest Jiaotong University, Chengdu, 610000, China.
}

\begin{abstract}
In terms of the existing solar heating system, its structure and control system are too complex and heat storage unit is too large, which makes it suitable for public buildings with large plot ratio or concentrated residential areas etc. But it is not suitable for rural residences with abundant solar energy resources, backward economic condition and scattered distribution of inhabitation. In this paper, we improve, optimize and integrate the existing solar heating system and design a new simple and reliable household solar heating system. In addition, we verify it by indoor temperature test and calculation of solar fraction in an actual project.
\end{abstract}

\section{Introduction}

The region of Western Sichuan Plateau mainly includes Ganzi Prefecture, Aba Prefecture, Liangshan Prefecture and Panzhihua City. According to the building climate division in China, it almost belongs to the cold or freezing area. According to the preliminary investigation, in the new residential buildings in Seda County, people still relies on fuelwood and dung stove for heating in winter. The total annual amount of solar radiation in Seda County reaches $6300.0 \mathrm{~W} / \mathrm{m} 2$. The total annual hours of sunshine are $2400.0 \mathrm{~h}$ or more. And the average daily hours of sunshine are more than $6.0 \mathrm{~h}$ for many years. In this region, daily light rate and sunshine radiation intensity are high, solar energy resources are rich and stable [1].

Since the 1990s, the state has invested a large amount of manpower and material resources to research and promote the application of solar energy in plateau regions. Si et al. proposed an optimization model of solar photovoltaic power generation system for office buildings or commercial buildings in alpine regions (Lhasa City) [2]. In order to promote the application of renewable energy in low energy consumption residential buildings in alpine areas (Xining City), Liu et al. studied solar air source heat pump system (SASHP) [3], which was concentrated in public buildings or residential areas in cities but few in rural residential areas with backward economic conditions and scattered distribution of inhabitation. In particular, except for a small number of very low-end, inefficient solar water heaters, there is no systematic research on the application of solar heating. Existing solar applications (whether active, passive solar heating, or solar photovoltaic reheating) are difficult to promote in this region. The reasons are mainly as follows: The climate in this region in winter is extremely harsh and the temperature difference between day and night is large; The demand for heating energy is large in winter and the demand for air conditioning is zero in summer, so the energy demand fluctuates greatly throughout the year; Due to the extreme lack of professional maintenance technicians, failures are difficult to solve in time; The living distribution of township and village level administrative units are scattered, most of the living environments in rural administrative areas are poor; Water, electricity supply are extremely unstable. The region is largely isolated.

\section{Existing solar systems are not suitable for scattered residences}

The existing solar heating systems include solar photovoltaic power generation reheating system and direct solar heating system (including active and passive solar systems). Solar photovoltaic power generation is a new type of power generation system that uses the photovoltaic effect of solar cell semiconductor materials to directly convert sunlight radiation into electric energy [4]. Active direct solar heating system is a heating system that uses heat collection devices installed on the roof or the ground to collect solar energy and then send the energy to the user. Passive direct solar heating system is a building that naturally acquires and uses solar heating by using reasonable building orientation, room layout, reasonable choice of building materials and energy-saving constructions. Due to the low energy density of solar energy itself, the active type cannot provide a huge amount of energy [5]. Therefore, passive forms such as the structure of buildings and additional sunlight space should be used at the same time to reduce energy loss and meet the requirement of heating, living and other energies.

*Corresponding author: 57897864@qq.com 


\subsection{The composition and control of the existing solar energy system are too complex for the new buildings in western Sichuan}

The results and discussion may be presented separately, or in one combined section, and may optionally be divided into headed subsections. The existing active solar energy system consists of three parts, the heat collecting side, including solar collector, heat storage tank or water tank, and heat collecting and circulating pump; Heat exchange side, includes plate exchange and heat exchange circulation pump; User side, including auxiliary heat source, heating circulating pump, heat transfer pipeline and cooling end etc.

The main reasons why the system structure is too complex are as follows: Water loop is too large and faced with the danger of freezing, so it needs antifreezing measures; The imbalance of heat in winter and summer requires anti-vaporization measures; The water quality requirements of solar heating system and heating system are different, so intermediate heat exchange measures are needed; Because the system is large and there are many monitoring points, the control system is too bloated.

\subsection{The volume requirement of existing heat storage equipment is too large for new buildings in western Sichuan}

At present, the heat storage mode of the solar energy system is the heat storage tank, which is used to store the heat collected by the collector and transfer it to users at the end of the room. In order to ensure the output of solar energy system and realize the stratification of hot and cold water storage pool, a large storage pool is needed. The volume is configured according to the solar collector area. If the volume is too small, it will result in the waste of heat collected by the collector system and even the blowout of the collector pipe due to vaporization. If the volume is too large, it will make water temperature in the hot water storage tank too low to use directly. According to all kinds of active solar energy systems [6] and each square meter of collector area corresponding to the volume of heat storage tank, which is shown in Table 1, it can be estimated that, for private residences whose building area are generally $200 \sim 300 \mathrm{~m}^{2}$, at least about $20 \mathrm{~m}^{3}$ is needed for the heat storage tank. If it is considered as $4 \mathrm{~m}$ long, $1 \mathrm{~m}$ thick and $5 \mathrm{~m}$ high, it is equivalent to needing a wall to install the tank. Considering the characteristics of new buildings in the Western Sichuan Plateau area, this problem leads to the fact that the traditional active solar energy system scheme of water thermal storage cannot be implemented in residential buildings at all.

Table 1. Volume selection range of heat storage tank

\begin{tabular}{|c|c|}
\hline System type & Volume of heat storage tank \\
\hline Small heating system & $40 \sim 100 \mathrm{~L} / \mathrm{m}^{3}$ \\
\hline $\begin{array}{c}\text { Short-term heat storage } \\
\text { system (user's heat for } 1 \text { to } 5 \\
\text { days) }\end{array}$ & $50 \sim 150 \mathrm{~L} / \mathrm{m}^{3}$ \\
\hline Seasonal heat storage system & $1400 \sim 2100 \mathrm{~L} / \mathrm{m}^{3}$ \\
\hline
\end{tabular}

\section{Design of complete equipment of new type solar energy system}

\subsection{Selection and placement of solar collector}

At present, the commonly used solar collectors in active solar systems are divided into ordinary flat-plate solar collectors, heat-pipe vacuum tube solar collectors and parabolic concentration-type solar collectors. The common flat-plate solar collector has the advantages of simple structure, low cost and low maintenance cost. Its disad-vantages include poor antifreeze ability and poor insulation effect. The heat pipe vac-uum tube collector has the advantages of fast start-up, freeze resistance and heat stamping, but its disadvantages are high cost and heavy weight. Parabolic solar collec-tors have the advantages of rapid heating and high heat collection temperature, while their disadvantages include accurate tracking of the sun, high investment and complex control system. Considering the advantages and disadvantages of each collector, the heat pipe vacuum tube collector is the first choice for the new household solar energy system because it is suitable for severe weather and easy to maintain. The heat collect-ing area should be calculated and determined according to the dynamic load of the heating house and the amount of sanitary hot water.

\subsection{Design of heat storage equipment}

At present, phase change materials have been applied to heat storage insulation, heat storage ceiling, phase change heat storage wall and other fields. But they have not been introduced into active solar energy systems. The characteristics of crystalline hydrated salt phase change material include cheap price, large thermal conductivity, large dissolution heat, large volume heat storage density, neutral, etc. These characteristics determine that it is the first choice for solar energy system heat storage material.

The system adopts phase change heat storage technology to replace the huge heat storage tank in the traditional active solar energy system in order to optimize the in-stallation space. Since the house cannot provide large installation space for heat stor-age components, and in order to integrate and simplify the system, the design inte-grates this component with the heat pipe collector. The structure of integrated equipment is shown in Figure 1. The basic heat storage unit in the integrated equipment is the encapsulated spherical phase variant in the phase change regenerator.

The working principles of the equipment are as follows: the water in the vacuum heat collecting tube is heated and its density is reduced. It enters into the phase change heat storage box by natural circulation to heat the spherical phase change heat storage body. The heated spherical phase change heat storage body changes from solid state to liquid state. The density of solid increases and it exits the hot water area at the top. After the hot water is cooled, it enters the vacuum tube again by natural circulation. The total volume of encapsulated 
spherical phase variants in the phase-change regen-erator should be calculated based on the solar heat collection. Since the water supply temperature of air conditioning and domestic hot water is generally $40 \sim 60^{\circ} \mathrm{C}$, the phase change temperature of phase change material is $60 \sim 70^{\circ} \mathrm{C}$, and the phase change en-thalpy of the corresponding crystalline hydrated salt is about $180(\mathrm{KJ} / \mathrm{kg})$.

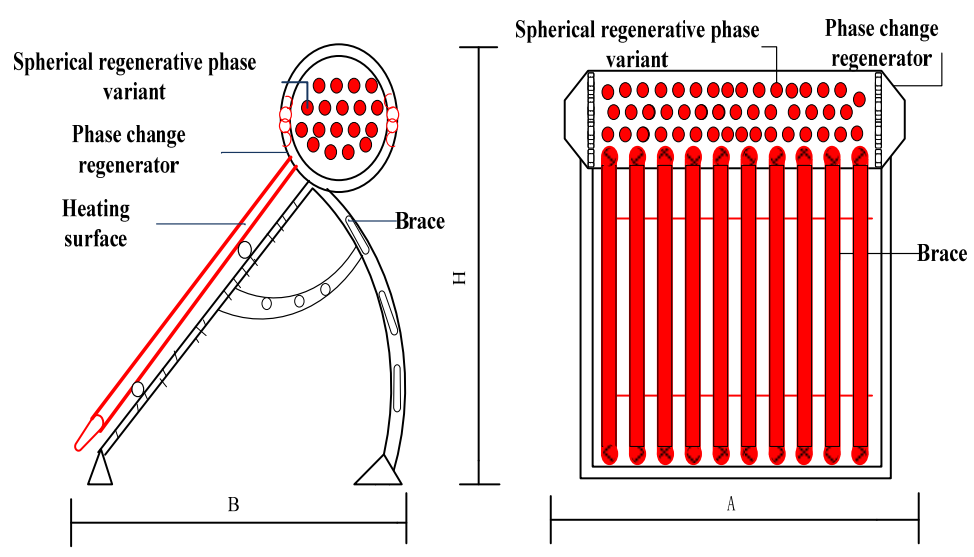

Figure 1. The structure of integrated equipment

\subsection{Working principles of the new solar energy system}

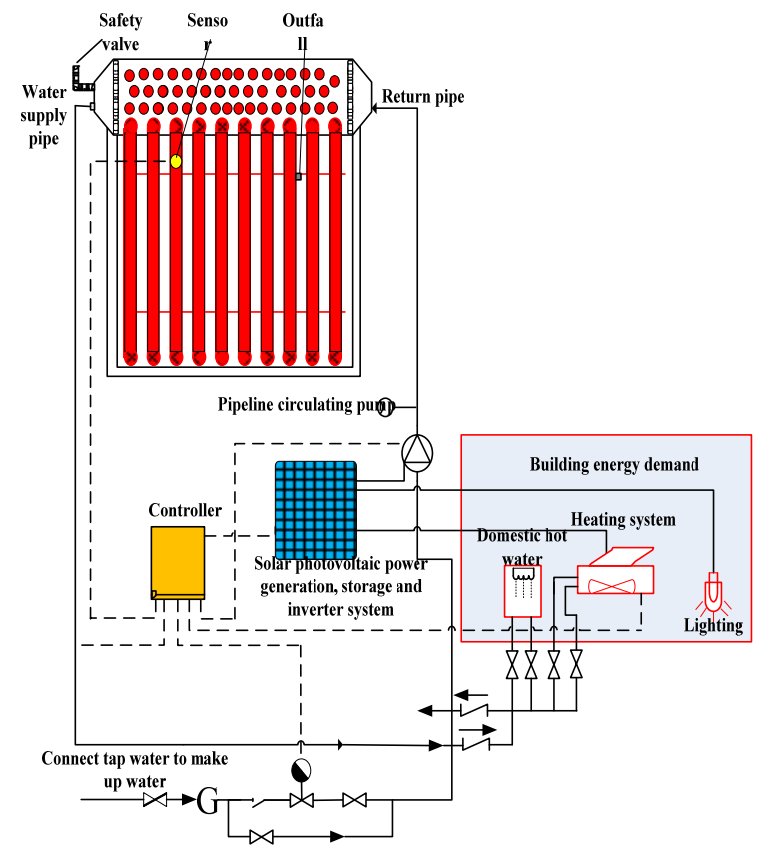

Figure 2. A new design of solar energy residential system

According to the improvement scheme of each part of solar energy system, the complete set of equipment of new-type solar energy system is optimized, integrated and designed as follows. The system is mainly composed of four parts: solar heat stor-age equipment, solar photovoltaic power generation and storage inverter equipment, hot water transmission and distribution equipment and pipe network, hot water fan coil unit and other end four parts. The solar heat collection and storage equipment, so-lar photovoltaic power generation and electric storage inverter equipment can be in-stalled on the roof, balcony or south wall, etc, which is with great flexibility in installa-tion. At the same time, the system is designed highly modular, building block assem-bly, easy to transport and install, which can achieve integration with the building.

According to the actual energy demand of the user, the complete equipment sys-tem installs the corresponding heat collection and storage integrated equipment on the roof, which is connected by pipelines with indoor air plates and domestic hot water to meet the user's heat demand. It is generated by the roof solar panel and stored in the battery bank, and supplied to the user's power demand by the inverter. See Figure 2 for the specific design.

\section{Engineering application}

\subsection{Energy-saving renovation of building envelope and installation of new solar energy complete set system}

Take Ese Sangzhu's house in Seda county as an example. The building is a typical two-story building. The first floor is the storage room and straw room, and the second floor is the daily house of the host family, with a building area of about $220 \mathrm{~m}^{2}$. See Table 2 for the thermal performance of the external protective struc-ture of the building. As can be seen from the calculation results in Table 2, the heat transfer coefficient of external walls and roofs is much higher than the national standard. Therefore, the passive solar energy saving renovation of the building's exteri-or wall and roof should be carried out first. The external wall is made of $80 \mathrm{~mm}$ thick EPS polystyrene board, and the expanded $120 \mathrm{~mm}$ thick perlite insulation layer is added to the roof to meet the requirements of the building energy conservation design code. According to the size of the building roof area and the installation re-quirements of the new solar energy complete set system, the effective solar energy heat collection area on the building roof is about $15 \mathrm{~m}^{2}$. According to the power load estimation, $5 \mathrm{~m}^{2}$ is used to place the solar photovoltaic power generation panel, and $10 \mathrm{~m}^{2}$ is used to place the complete set of solar energy heat collection and storage equipment. 
Table 2 Thermal performance table of envelope

\begin{tabular}{|c|c|c|c|c|c|}
\hline \multicolumn{3}{|c|}{ Exterior wall } & \multicolumn{2}{c|}{ Roof } \\
\hline Material & $\begin{array}{c}\text { Thickness } \\
\delta\end{array}$ & $\begin{array}{c}\text { Thermal } \\
\text { conductivity } \lambda\end{array}$ & Material & $\begin{array}{c}\text { Thickness } \\
\delta\end{array}$ & $\begin{array}{c}\text { Thermal } \\
\text { conductivity } \lambda\end{array}$ \\
\hline $\begin{array}{c}\text { From outside to } \\
\text { inside }\end{array}$ & $\mathrm{mm}$ & $\mathrm{W} /(\mathrm{m} \cdot \mathrm{K})$ & $\begin{array}{c}\text { From outside to } \\
\text { inside }\end{array}$ & $\mathrm{mm} /(\mathrm{m} \cdot \mathrm{K})$ \\
\hline $\begin{array}{c}\text { Cement mortar } \\
\text { Sandstone concrete }\end{array}$ & 20 & 0.93 & Expanded perlite & 80 & 0.07 \\
\hline $\begin{array}{c}\text { Lime cement mortar } \\
\text { The sum of each } \\
\text { layer }\end{array}$ & 20 & 1.28 & Cement mortar & 100 & 0.93 \\
\hline $\begin{array}{c}\text { Heat transfer } \\
\text { coefficient } \mathrm{k}\end{array}$ & 280 & 0.87 & Reinforced concrete & 120 & 1.74 \\
\hline National standard & \multicolumn{2}{|c|}{$\leq 0.45 \mathrm{~W} /\left(\mathrm{m}^{2} \mathrm{~K}\right)$} & $\begin{array}{c}\text { Heat transfer } \\
\text { coefficient } \mathrm{k}\end{array}$ & National standard & \\
\hline
\end{tabular}

\subsection{Indoor temperature measurement and dynamic load calculation of buildings}

After the renovation of the new solar energy house of Sangzhu's family in Seda County, the indoor temperature of the second floor was tested for two consecutive days from January 25 to 26 . It can be seen from the indoor temperature data of the test room in Figure 3 that the minimum temperature was $13.6^{\circ} \mathrm{C}$ in the three hours from 2:00 a.m. to 5:00 a.m. on January 25. The rest met the requirements of the national standard minimum limit value of $15^{\circ} \mathrm{C}$, which verified that the scheme met the requirements of indoor thermal comfort.

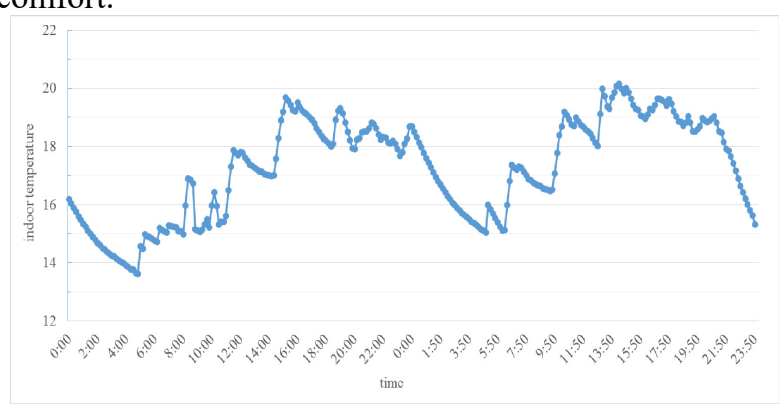

Figure 3. Test room temperature

Solar heating guarantee rate (Solar fraction for short) is an important index of solar energy building. It refers to the percentage of total heat load of the system occupied by the heat supplied by solar energy in the solar heating system. According to the design temperature of $18^{\circ} \mathrm{C}$ in winter, when the solar heating system is insufficient, it can rely on electric energy for heating. The annual solar fraction $f$ of the new solar energy complete set system is calculated to be $64 \%$ (see Figure 4), which meets the requirement of specification [6] for solar fraction of solar energy hot water system in areas with abundant solar energy resources $\geq 50 \%$.

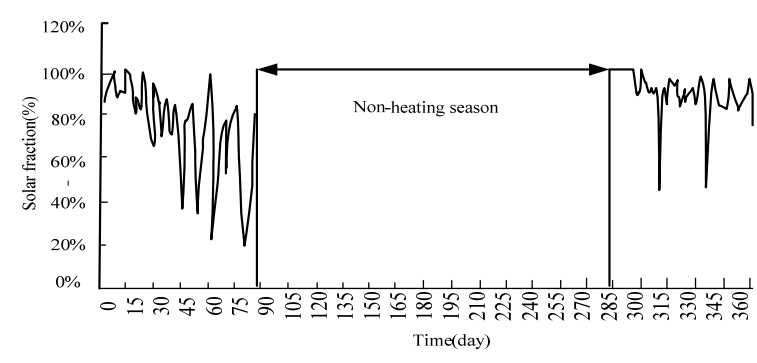

Figure 4. Daily solar fraction

\section{Conclusions}

Considering the climate characteristics and the requirements of household type residences in the plateau area of Western Sichuan, this paper designs and optimizes the solar energy residential system in this area, solves the problems of complexity of the traditional active solar energy system, high investment, large amount of maintenance and too large heat storage unit, and realizes modular design, which is convenient for industrial manufacturing, simple installation, reliable operation and so on. It has been verified by the actual project of Ese Sangzhu's house in Seda County. The integrated equipment of heat collection and storage based on vacuum tube collector and phase change material in the new solar energy system is suitable for the household residences in this area. The device can effectively save the volume of the heat storage unit and simplify the system structure. The household photovoltaic power supply system in the new solar energy system can solve the situation that there is no stable power supply in the remote areas of the plateau in winter. The new solar energy system can meet the requirement of indoor thermal comfort when it is applied in residential buildings in western Sichuan Plateau area. And the solar fraction of the new solar energy system is far higher than the standard by calculating the daily solar fraction.

\section{Acknowledgments}

This work is supported by the Natural Science Project of Sichuan Education Department (Grant No. 16ZB0371) 


\section{References}

1. Y. C. Zhong, Z. F. Ma, J. X. Xu and H. Y. Guo, "Assessment of Solar Energy Resource in Sichuan Based on Distributed Modeling on Rugged Terrains, " Journal of Southwest University (Natural Science), no. 7, pp. 115-121, 2018.

2. P. F. Si, Y. Feng, Y. X. Lv, X.Y. Rong et al., "An Optimization Method Applied to Active Solar Energy Systems for Buildings in Cold Plateau Areas - the Case of Lhasa," Applied Energy, vol. 194, pp. 487-498, 2017.

3. Z. J. Liu, Y.W. Liu, D. Wu et al., "Wensheng Ma, Performance and feasibility study of solar-air source pump systems for low-energy residential buildings in Alpine regions, "Journal of Cleaner Production, vol. 256, Article ID 120735, 2020.

4. J. I. Kwak, S. H. Nam, L. Kim, Y. J. An, "Potential environmental risk of solar cells: Current knowledge and future challenges" , Journal of Hazardous Materials, vol. 392, Article ID 122297, 2020.

5. P. F. Si, Y. X. Lv, X.Y. Rong et al., "An innovative building envelope with variable thermal performance for passive heating systems," Applied Energy, Volume 269, Article ID115175, 2020.

6. National standards of the people's Republic of China, Technical standard for solar water heating system of civil buildings (GB50364-2018) [S], China Architecture\& Building Press, 2018. 